inadequacy of their food supply now that the game, which was formerly their subsistence, has become scarce. Here the Department has embarked on an extensive educational programme in agriculture with a scheme of assistance, for which great success is claimed. Through it some hundreds of Indians have become entirely self-supporting by agriculture within two generations. About one third of the Indians still live the traditional nomadic life in the northern hinterland with the easily moved tepee as their home and hunting and trapping as their means of subsistence.

\section{Archæological Excavations in Syria}

SIR LEONARD WoOLIEY's account of the first month's work on the British Museum's new archæo. logical site in Syria fully confirms anticipation of the nature of the evidence likely to be obtained at such a point as the mouth of the Orontes, which must have been an important centre of international and commercial intercourse from early times. Tel Sheikh Yusuf el Gharib, a low mound, so called after a local saint, on the right bank of the Orontes, he reports in The Times of June 4, has produced evidence of nine occupation levels. As virgin soil has been reached just below deposits which are dated at about the twelfth century B.c., it is evident that the mound begins with what can only be a later extension of the main settlement. Although in consequence no material of Mycenæan age or earlier is forthcoming, it has yielded finds of considerable interest and no little importance. The pottery, for example, includes possibly the finest example of Proto-Corinthian ware yet known, while the so-called 'Cypriote' ware, a class of ceramics appearing in Cyprus in the Early Iron Age without known local antecedents, occurs here rather earlier in the eighth level in such sudden abundance as to suggest a violent occupation, and possibly may eventually afford a clue to the cultural origins of this type in Asia. Especially fine examples of orientalising Agean wares of the best sorts from the sixth and fifth levels, and innumerable fine fragments of Attic wares, belonging to the late sixth and fifth centuries B.c., some of which can be recognised as by known artists, from the fourth level point, in Sir Leonard's opinion, not only to a flourishing luxury trade with the Egean, but also to great enterprise on the part of the Athenians in establishing a flourishing commercial centre on this Asiatic coast at a time of tension with the great imperial power of Persia. Evidence was also obtained of intercourse with the Asiatic interior, the occurrence of a basalt bowl, showing a debased Hittite style in decoration, being noted. Such results in a restricted area afford abundant promise from future excavation.

\section{British Standards Institution}

THE annual general meeting of the British Standards Institution was held at the Institution of Mechanical Engineers on June 4, under the chairmanship of Mr. W. Reavell. In reporting on the progress of the work during his year of office, $\mathrm{Mr}$. Reavell made reference to the arbitration in con- nexion with the standards to be adopted in Great Britain for the $16-\mathrm{mm}$. sound films which, at the invitation of the General Council, Lord Riverdale had undertaken in February last, and the decision of which is now being loyally adopted throughout the industry. Mention was also made of the forth. coming visit of the director to New York and the Argentine in connexion with the work of the newly formed Argentine Institute for the Rationalisation of Materials. At the luncheon which followed the meeting, Lord Riverdale referred to the very economic manner in which the work is carried out, dealing as it now does with some eight hundred committees and more than a thousand meetings a year. Some people fear that standardisation means stagnation, but this is provided against in the precautions the B.S.I. takes when standards are brought into being and in the frequent review and revision of those standards. Industry does not fully appreciate the value of standardisation in the matter of capital expenditure. It means the possibility of reduction of stocks which in turn means liberating capital, and this might amount to millions of pounds in the British Empire.

Mr. E. J. Elford, the chairman for the forthcoming year, said that the British Standards Institution is greatly indebted not only to the Government for its continued financial support, to the many technical officers of the various Government departments for their assistance on the technical work, but also to the hundreds of representatives of industryusing that word in the widest sense who give their time and experience so willingly to this work of growing national importance. Mr. S. Tatchell, chairman of the Building Industries National Council, stressed the great importance to the building industry of the closest co-operation between his Council and the B.S.I., and referred to the agreements recently come to which have been set out in their Report on Standardisation Policy. Colonel Briggs, of Messrs. Unilevers, expressed the satisfaction of the chemical industry at the work already undertaken by the Institution in the chemical field and its desire to co-operate in future work of the Institution.

\section{The Development Fund}

THE twenty-fifth report of the Development Commissioners for the year ending March 1935 has now been published (London: H.M. Stationery Office. 2s. 6d. net). The function of the Commissioners is to make a thorough examination of applications for grants from the fund, amending or vetoing the schemes submitted if necessary, and afterwards to recommend to the Treasury what advances shall be made. The majority of the schemes aided call for recurrent expenditure, and as advances are made annually the progress of the work is kept under continuous review. Agriculture and rural economy comprise the main bulk of the expenditure, as under this heading come the regular grants to research institutes, advisory centres and rural industries, as well as the special grants, research scholarships and studentships. A short account of each institute is given, describing the type of work undertaken and 